\title{
PENGARUH LINGKUNGAN KERJA DAN KOMPENSASI TERHADAP KEPUASAN KERJA KARYAWAN PT. CIPTA MANDIRI WIRASAKTI
}

\author{
Rut Masna Lamminar 1) \\ 1) Mahasiswa Program Studi Manajemen FE UNKRIS \\ Bongsu Saragih 2) \\ 2) Dosen Program Studi Manajemen FE UNKRIS \\ Alamat: Kampus UNKRIS, Jatiwaringin Jakarta Timur \\ Email : bongsu.saragih@gmail.com
}

\begin{abstract}
To determine the effect of Work Environment and Compensation on Employee Job Satisfaction PT. Cipta Mandiri Wirasakti. This research uses a quantitative approach, namely through the causal type inferential analysis. This research seeks to examine the effect of the independent variable on the dependent variable. In this study the population is the employees of PT. Cipta Mandiri Wirasakti with 440 employees. Based on the Slovin formula, the sample in this study was 82 people. Collecting data in this study using a closed questionnaire. The analysis method used partially and simultaneous linear regression analysis. Based on the results of the analysis, then 1). There is a positive and significant influence between the work environment on employee job satisfaction. 2). There is a positive and significant influence between compensation on employee job satisfaction. 3). There is a significant influence between work environment and compensation on job satisfaction of employees of PT. Cipta Mandiri Wirasakti.
\end{abstract}

Keywords: Work environment, compensation and job satisfaction

\section{PENDAHULUAN}

Perkembangan teknologi di zaman modern yang sangat pesat membawa perubahan dalam kehidupan dan perkembangan teknologi yang tidak dapat dihindarkan ini dapat berpengaruh pada perusahaan yang dalam perkembangannya sangat membutuhkan keahlian dan kemampuan agar perusahaan mampu bertahan, dengan tujuan memperoleh laba seoptimal mungkin untuk mempertahankan kelangsungan hidup perusahaan dan mengembangkan usahanya lebih jauh serta dapat mencapai suatu sasaran yang telah ditetapkan. Dengan adanya keahlian dan kemampuan tersebut diharapkan keuntungan yang diperoleh dapat membiayai semua aktivitas perusahaan, sehingga kehidupan perusahaan akan tetap berlangsung.

Untuk menyusun strategi perusahaan agar dapat berjalan secara efektif dan efisien sesuai dengan tujuan yang diharapkan maka perusahaan harus memperhatikan unsur manajemen. Prinsip dari manajemen adalah mengatur kegiatan perusahaan agar berjalan dengan baik, efektif dan efisien melalui pemanfaatan sumber daya manusia yang dimiliki secara maksimal. Sumber daya manusia merupakan aset perusahaan yang sangat vital dimana peran dan fungsinya tidak dapat digantikan oleh sumber daya lainnya. Sumber daya manusia memiliki peran yang sangat besar dalam menentukan maju mundurnya 
perusahaan. Oleh karena itu, salah satu faktor kemajuan suatu perusahaan ditentukan pula oleh kualitas sumber daya manusia di dalamnya. Tanpa peran manusia meskipun berbagai faktor yang dibutuhkan itu telah tersedia, perusahaan tidak akan berjalan. Karena manusia merupakan penggerak dan penentu jalannya suatu perusahaan. Oieh karena itu hendaknya perusahaan memberikan arahan yang positif demi tercapainya tujuan perusahaan.

Suatu perusahaan akan meningkat kinerjanya bila adanya kerjasama dan hubungan yang baik antara pimpinan dan karyawannya. Karena dengan meningkatkan kerjasama dan hubungan baik secara langsung akan meningkatkan kinerja perusahaan itu sendiri. Dan karyawanpun sebaiknya diperlakukan seperti partner usaha dan bukan sebagai buruh semata. Persoalan karyawan yang terkadang dibuat seperti buruh-buruh yang fasilitas dan pelayanan kurang diperhatikan oieh para pimpinannya. Dan tidak adanya hubungan dan kerjasama yang baik antar mereka. Persoalan ini tidak hanya terjadi di negara-negara yang sedang berkembang tetapi terjadi juga dinegara maju persoalan tersebut, walaupun penyebabnya berbeda.

Banyak faktor yang mempengaruhi keberhasilan suatu perusahaan, salah satunya adalah karyawan, karena berkaitan langsung dengan kegiatan perusahaan. Dalam hal ini karyawan diharapkan dapat memberikan hasil yang maksimal sehingga tujuan dari perusahaan dapat tercapai. Kepuasan kerja merupakan salah satu faktor bagi karyawan agar dapat bekerja secara maksimal. Menurut Dawal dan Taha (2006) menyatakan bahwa "kepuasan kerja bagi karyawan merupakan kunci dari sehatnya sebuah perusahaan". banyak faktor yang dapat mempengaruhi kepuasan kerja karyawan seperti yang disampaikan oleh Sutrisno, (2016), "adanya kesempatan untuk maju, keamanan dalam bekerja, kepuaan atas gaji yang diterima, perusahaan dan manajemen yang baik, adanya pengawasan dari supervisi, faktor intrisik dari pekerjaan, kondisi tempat kerja, aspek sosial dalam pekerjaan, komunikasi antar karyawan yang harmonis, dan tersedianya fasilitas yang baik dari perusahaan".

Kondisi lingkungan kerja yang nyaman akan mempengaruhi kepuasan kerja karyawan dalam bekerja dan akan lebih giat serta konsentrasi menyelesaikan tugas-tugasnya sesuai jadwal. Selain itu lingkungan kerja yang baik akan membantu mengurangi kejenuhan dan kelelahan, sehingga diharapkan dapat meningkatkan kepuasan kerja karyawan. Lingkungan kerja menurut Saydam (2014), "sebagai keseluruhan sarana prasarana kerja yang ada disekitar karyawan yang sedang melaksanakan pekerjaan yang dapat mempengaruhi pekerjaan itu sendiri". Walaupun lingkungan kerja merupakan faktor penting serta dapat mempengaruhi kinerja karyawan, tetapi saat ini masih banyak perusahaan yang kurang memperhatikan kondisi lingkungan kerja disekitar perusahaan. Suatu kondisi lingkungan kerja dapat dikatakan baik apabila lingkungan kerja tersebut sehat, nyaman, aman dan menyenangkan bagi karyawan dalam menyelesaikan pekerjaannya.

Selain lingkungan kerja faktor lain yang dapat mempengaruhi kepuasan kerja karyawan adalah masalah kompensasi. Bagi karyawan, kompensasi dipandang sebagai alat untuk mempertahankan kelangsungan hidupnya secara ekonomis. Kompensasi dapat berupa gaji dan insentif yang langsung diberikan kepada karyawan. Besar kecilnya kompensasi terkadang tidak sesuai dengan apa yang dikerjakan karyawan, tentunya ini dapat mempengaruhi kepuasan kerja karyawan dan dampaknya akan menimbulkan halhal yang tidak diinginkan dan dapat merugikan perusahaan yang bersangkutan. 
Kompensasi menurut Hasibuan (2017) Kompensasi adalah "semua pendapatan yang berbentuk uang, barang langsung atau tidak langsung yang diterima karyawan sebagai immbalan atas jasa yang diberikan kepada perusahaan". Kompensasi merupakan balas jasa atas apa yang telah dilakukan, dikerjakan, dan disumbangkannya baik tenaga, pikiran, ide, dan kemampuan dalam mencapai tujuan perusahaan. Masalah kompensasi merupakan fungsi manajemen sumber daya manusia yang paling sulit dan membingungkan, tidak hanya karena pemberian kompensasi yang merupakan salah satu tugas yang paling kompleks, tetapi juga salah satu aspek yang paling baik bagi karyawan maupun perusahaan. Meskipun kompensasi harus mempunyai dasar yang logis, rasional, dan dapat dipertahankan hal ini menyangkut banyak faktor emosional dan dari sudut pandang para karyawan.

PT. Cipta Mandiri Wirasakti adalah salah satu produsen terkemuka wiring harness otomotif dan cablings listrik di Indonesia. Kami telah melayani industri automative selama bertahun-tahun baik di motorcyles dan mobil OEM (Original Equipment Manufacturing) manufaktur. Selain itu, kami juga memperluas produk kami untuk jenis lain cablings listrik untuk mobil, generator, dan bahkan kapal. Organisasi kami telah mencapai ISO / TS 16949: 2009 ISO Spesifikasi Teknis. Pencapaian ini adalah untuk memastikan fokus konstan dalam tepat waktu deliverence serta kualitas produk kami yang memenuhi atau melampaui tuntutan pelanggan everchanging. Kami menjamin kepuasan pelanggan kami dengan membawa keluar yang terbaik dari tim pekerja keras dan inovatif kami orang sebagai bagian dari organisasi kami yang dinamis

Kami menjamin kepuasan pelanggan kami dengan membawa keluar yang terbaik dari tim pekerja keras dan inovatif kami orang sebagai bagian dari organisasi kami yang dinamis. Berkurangnya kepuasan kerja karyawan ini terlihat dari ketatnya peraturan pada PT. Cipta Mandiri Wirasakti yang diterapkannya, sehingga karyawan merasa mengeluh, karena tidak mempunyai kesempatan untuk berlibur untuk berekreasi. Hal ini pada akhimya akan menurunkan kinerja perusahaan itu sendiri. Maka, manajemen sebaiknya memahami apa yang dibutuhkan para karyawan dan mengetahui keinginankeinginan apa yang dapat meningkatkan kinerja karyawan. Permasalahan lain yang dikeluhkan karyawan adalah kompensasi, yaitu berupa gaji dan insentif. Masalah yang yang dikeluhkan karyawan mengenai kompensasi yaitu agak telat waktu pemberian gaji karyawan. Selain itu, insentif yang diterimapun terkadang tidak sesuai dengan apa yang diharapkan.

Tujuan penelitian ini adalah untuk mengetahui pengaruh lingkungan kerja dan kompensasi terhadap kepuasan kerja karyawan PT. Cipta Mandiri Wirasakti.

\section{LANDASAN TEORI}

\section{Kepuasan Kerja}

Kepuasan kerja adalah tingkat kesenangan yang dirasakan seseorang atas peranan atau pekerjaannya dalam organisasi. Tingkat rasa puas individu bahwa mereka mendapat imbalan yang setimpal dari bermacam-macam aspek situasi pekerjaan dari organisasi tempat mereka bekerja. Jadi kepuasan kerja menyangkut psikologis individu didalam organisasi, yang diakibatkan oleh keadaan yang ia rasakan dari lingkungannya.

$$
\text { Menurut Handoko (2017) }
$$

mengemukakan bahwa kepuasan kerja (Job Satisfaction) adalah "keadaan emosional yang menyenangkan atau tidak menyenangkan dengan para karyawan memandang pekerjaan mereka. Waktu/lama penyelesaian merupakan pencerminan perasaan seseorang terhadap 
pekerjaannya. Ini dapat dilihat dari sikap positif karyawan terhadap pekerjaan dan segala sesuatu di lingkungannya". Sedangkan menurut Afandi, (2018), kepuasan kerja adalah "sikap yang positif dari tenaga kerja meliputi perasaan dan tingkah laku terhadap pekerjaannya melalui penilaian salah satu pekerjaan sebagai rasa menghargai dalam mencapai salah satu nilai-nilai penting pekerjaan”. Selanjutnya dalam Robbins (2007) disebutkan bahwa kepuasan kerja adalah "suatu sikap umum terhadap pekerjaan seseorang sebagai perbedaan antara banyaknya ganjaran yang diterima pekerja dengan banyaknya ganjaran yang diyakini seharusnya diterima”. Kepuasan kerja merupakan hal penting yang dimiliki individu di dalam bekerja. Setiap individu pekerja memiliki karakteristik yang berbeda-beda, maka tingkat kepuasan kerjanya pun berbedabeda pula tinggi rendahya kepuasan kerja tersebut dapat memberikan dampakyang tidak sama.

Kemudian menurut Sutrisno (2016) mengemukakan kepuasan kerja adalah "keadaan emosional yang menyenangkan atau tidak menyenangkan bagi para pekerja memandang pekerjaan mereka". Kepuasan kerja mencerminkan perasaan seeorang terhadap pekerjaannya. Priansa (2016) menyampaikan kepuasan kerja "merupakan perasaan pekerja terhadap pekerjaannya, apakah senang atau suka atau tidak senang atau tidak suka sebagai hasil interaksi pekerjadengan lingkungan pekerjaannya atau sebagai presepsi sikap mental, juga sebagai hasil penilaian pekerja terhadap pekerjaannya". Perasaan pekerja terhadap pekerjaannya mencerminkan sikap dan perilakunya dalam bekerja.

Berdasarkan pengertian kepuasan kerja dapat disimpulkan bahwa kepuasan kerja adalah suatu pandangan dan sikap seseorang baik positif maupun negatif mengenai penilaian seseorang terhadap pekerjaan mereka.
Faktor-faktor yang mempengaruhi kepuasan kerja, menurut Mangkunegara (2017) yaitu: 1). "Faktor pegawai, yaitu kecerdasan (IQ), kecakapan khusus, umur, jenis kelamin, kondisi fisik, pendidikan, pengalam kerja, masa kerja, kepribadian, emosi, cara berfikir, persepsi, dan sikap kerja. 2). Faktor pekerjaan, yaitu jenis pekerjaan, struktur organisasi, pangkat (golongan), kedudukan, mutu pengawasan, jaminan finansial, kesempatan promosi jabatan, interaksi social, dan hubungan kerja".

Adapun indikator kepuasan kerja dikompilasidari penelitian yang dilakukan oleh Colquitt et al., (2013) dalam Hasibuan, (2017) yang akan digunakan dalam penelitian ini diantaranya adalah: 1). "Pekerjaan itu sendiri; Pekerjaan yang sesuai merupakan kepuasan karyawan, dimana pekerjaan sebagai kesempatan untuk belajar, menerima tanggung jawab dan kemajuan karyawan. 2). Gaji; Jumlah gaji yang diberikan perusahaan kepada karyawan harus sesuai dengan beban kerja yang dikerjakan karyawan. 3). Promosi; Promosi memiliki sejumlah bentuk yang berbeda dan memiliki penghargaan, seperti promosi atas dasar senioritas atau kinerja dan promosi kenaikan gaji. 4). Pengawasan; Gaya pengawasan dapat mempengaruhi kepuasan kerja. Pengawasan berpusat pada karyawan dan iklim partisipasi atau pengaruh dalam pengambilan keputusan yang dapat mempengaruhi pekerjaan karyawan. 5). Rekan kerja; Kelompok kerja saling tergantung antar anggota dalam menyelesaikan pekerjaan. Kondisi ini membuat pekerjaan menjadi lebih efektif, sehingga membawa efek positif yang tinggi pada kepuasan kerja".

\section{Lingkungan Kerja}

Lingkungan kerja adalah tempat dimana karyawan melakukan aktivitas setiap harinya. Lingkungan kerja yang 
kondusif memberikan rasa aman dan memungkinkan karyawan untuk bekerja optimal. Lingkungan kerja dapat mempengaruhi emosi karyawan. Jika karyawan menyenangi lingkungan kerja dimana dia bekerja, maka karyawan tersebut akan merasa nyaman di tempat kerjanya, melakukan aktivitas sehingga waktu kerja dipergunakan secara efektif. Lingkungan kerja itu mencakup hubungan kerja yang terbentuk antara sesama karyawan dan hubungan kerja antara bawahan danatasan serta lingkungan fisik tempat karyawan bekerja.

Menurut Rivai (2015), lingkungan kerja merupakan "elemen- elemen organisasi sebagai sistem sosial yang mempunyai pengaruh yang kuat di dalam pembentukan perliaku individu pada organisasi dan berpengaruh terhadap prestasi organisasi". Sedangkan menurut Sedarmayanti (2017) defenisi lingkungan kerja adalah "keseluruhan alat perkakas dan bahan yang dihadapi, lingkungan sekitarnya di mana seseorang bekerja, metode kerjanya, serta pengaturan kerjanya baik sebagai perseorangan maupun sebagai kelompok". Menurut Casson (2013) lingkungan kerja adalah "sesuatu dari lingkungan pekerjaan yang memudahkan atau menyulitkan pekerjaan". Menyenangkan atau menyulitkan mereka termasuk didalamnya adalah faktor penerangan, suhu udara, ventilasi, kursi dan meja tulis.

Pengertian lingkungan kerja yang dikemukakan oleh Nitisemito (2015), bahwa lingkungan kerja adalah "segala sesuatu yang ada disekitar para pekerja dan yang dapat mempengaruhi diri pekerja dalam menjalankan tugas- tugas yang dibebankan kepadanya". Hal ini semakin diperkuat dengan pendapat Ahyari (2014) bahwa lingkungan kerja adalah "berkaitan dengan segala sesuatu yang berada disekitar pekerjaan dan yang dapat mempengaruhi karyawan dalam melaksanakan tugasnya, seperti pelayanan karyawan, kondisi kerja, dan hubungan karyawan di dalam perusahaan yang bersangkutan".

Berdasarkan pengertian tersebut, maka dapat diambil suatu kesimpulan bahwa lingkungan kerja merupakan suatu alat perkakas yang ada disekitar pegawai, misalnya berupa meja, kursi, laptop, suhu, dll. Hal ini akan berpengaruh dengan kinerja yang dilakukan oleh pegawai. Jika kondisi lingkungan kerja itu sudah baik dan kondusif maka pegawai bisa menghasilkan kinerja yang baik serta produktifitas yang meningkat, dan begitu juga sebaliknya.

Lingkungan kerja menurut Sedarmayati, (2017) dibagi menjadi dua jenis yaitu: 1). "Lingkungan Kerja Fisik; Lingkungan kerja fisik dapat diartikan semua keadaan yang ada disekitar tempat kerja, yang dapat mempengaruhi kinerja karyawan. yang dimaksud lingkungan kerja fisik yaitu semua keadaan berbentuk fisik yang terdapat disekitar tempat kerja dimana dapat mempengaruhi kerja karyawan baik secara langsung maupun tidak langsung. 2). Lingkungan Kerja Non Fisik; Llingkungan kerja non fisik adalah semua keadaan yang terjadi yang berkaitan dengan hubungan kerja, baik dengan atasan maupun dengan sesama rekan kerja, ataupun dengan bawahan".

Lingkungan kerja yang baik dapat memicu produktifitas dan kepuasan kerja karyawan. Siagian (2015), mengemukakan bahwa manfaat lingkungan kerja adalah "menciptakan gairah kerja, sehingga produktivitas dan prestasi kerja meningkat,selain itu lingkungan kerja juga dapat berpengaruh terhadap kepuasan kerja karyawan". Kepuasan kerja muncul sebagai akibat dari situasi kerja yang ada di dalam perusahaan. Kepuasan kerja tersebut mencerminkan perasaan karyawan mengenai senang atau tidak senang, nyaman atau tidak nyaman atas lingkungan kerja perusahaan dimana dia bekerja. 
Lingkungan kerja di perusahaan terbagi ke dalam dua indikator menurut Siagian (2015), yaitu:

1). "Lingkungan Kerja Fisik; Lingkungan kerja fisik adalah "semua keadaan berbentuk fisik yang terdapat disekitar tempat kerja dan dapat mempengaruhi karyawan”. Lingkungan kerja fisik terdiri dari : a). Bangunan tempat kerja; Bangunan tempat kerja di samping menarik untuk dipandang juga dibangun dengan pertimbangan keselamatan kerja, agar karyawan merasa nyaman dan aman dalam melakukan pekerjaannya. b). Peralatan kerja yang memadai; Peralatan yang memadai sangat dibutuhkan karyawan karena akan mendukung karyawan dalam menyelesaikan tugas yang di embannya di dalam perusahaan. c). Fasilitas; Fasilitas perusahaan sangat dibutuhkan oleh karyawan sebagai pendukung dalam menyelasikan pekerjaan yang ada di perusahaan. Selain itu ada hal yang perlu di perhatikan oleh perusahaan yakni tentang cara memanusiakan karyawannya, seperti tersedianya fasilitas untuk karyawan beristirahat setelah lelah bekerja dan juga tersedianya tempat ibadah. d). Tersedianya sarana angkutan; Tersedianya sarana angkutan akan mendukung para karyawan untuk sampai di tempat kerja dengan tepat waktu, baik yang diperuntukkan karyawan maupun angkutan umum yang nyaman, murah dan mudah di peroleh. 2). Lingkungan Kerja Non Fisik; Lingkungan kerja non fisik adalah "terciptanya hubungan kerja yang harmonis antara karyawan dan atasan". lingkungan kerja non fisik terdiri dari beberapa: a). Hubungan rekan kerja setingkat; hubungan dengan rekan kerja yaitu hubungan dengan rekan kerja yang harmonis dan tanpa saling intrik di antara sesama rekan sekerja. Salah satu faktor yang dapat mempengaruhi karyawan tetap tinggal dalam satu organisasi adalah adanya hubungan yang harmonis dan kekeluargaan. b). Hubungan atasan dengan karyawan: Hubungan atasan dengan bawahan atau karyawannya harus di jaga dengan baik dan harus saling menghargai antara atasan dengan bawahan, dengan saling menghargai maka akan menimbulkan rasa hormat diantara individu masing-masing.

Kerjasama antar karyawan; Kerjasama antara karyawan harus dijaga dengan baik, karena akan mempengaruhi pekerjaan yang mereka lakukan. Jika kerjasama antara karyawan dapat terjalin dengan baik maka karyawan dapat menyelesaikan pekerjaan mereka secara efektif dan efisien".

\section{Kompensasi}

Menurut Mangkunegara (2017), kompensasi adalah "sesuatu yang dipertimbangkan sebagai suatu yang sebanding". Dalam kepegawaian, hadiah yang bersifat uang merupakan kompensasi yang diberikan kepada pegawai sebagai penghargaan dari pelayanan mereka. Sedangkan Sunyoto (2012), kompensasi adalah "konsep yang lebih luas, kompensasi adalah semua bentuk kembalian atau imbalan (return) finansial, jasa-jasa berwujud dan tujuan-tujuan yang diperoleh sebagai dari sebuah hubungan kepegawaian".

Wibowo (2014) Pengertian kompensasi adalah "kontrak prestasi terhadap penggunaan tenaga atau jasa yang telah diberikan oleh tenaga kerja". Selanjutnya Dessler (2015), menyampaikan kompensasi adalah "setiap bentuk pembayaran atau imbalan yang diberikan kepada karyawan dan timbul dari diperkerjakannya karyawan itu".

$$
\text { Menurut Nawawi (2012), }
$$

kompensasi dalam hal ini dapat dikategorikan kedalam dua golongan besar yaitu: 1). "Kompensasi langsung artinya adalah suatu balas jasa yang diberikan perusahaan kepada karyawan karena telah memberikan prestasinya demi kepentigan perusahaan. Kompensassi ini diberikan, karena 
berkaitan secara langsung dengan pekerjaan yang dilakukan oleh karyawan tersebut. Contohnya: upah/gaji, insentif/bonus, tunjangan jabatan. 2). Kompensasi tidak langsung adalah pemberian kompensasi kepada karyawan sebagai tambahan yang didasarkan kepada kebijakan pimpinan dalam rangka upaya meningkatkan kesejahteraan karyawan. Tentu kompensasi ini tidak secara langsung berkaitan dengan pekerjaan yang dilakukan oleh karyawan tersebut. Contoh: tunjangan hari raya, tunjangan pensiun, tunjangan kesehatan dan lainnya".

Tujuan pemberian kompensasi menurut Notoatmodjo (2009), yaitu: 1). "Untuk menghargai prestasi karyawan. 2). Untuk menjamin keadilan gaji karyawan. 3). Untuk mempertahankan karyawan atau mengurangi turnover karyawan.

4). Untuk mendapatkan karyawan yang bermutu. 5). Untuk mengendalikan biaya. 6). Untuk memenuhi peraturanperaturan".

Menurut Sutrisno, (2016) mengemukakan bahwa besar kecilnya kompensasi dipengaruhi oleh beberapa faktor. Faktor-faktor yang memengaruhi besarnya kompensasi tersebut di antaranya adalah sebagai berikut: 1). "Adanya permintaan dan penawaran tenaga kerja; Perminntaan tenaga kerja artinya pihak perusahaan sangat membutuhkan tenaga kerja, maka secara otomatis kompensasi relatif tinggi. Penawaran tenaga kerja artinya pihak individu yang membutuhkan pekerjaan, maka tingkat kompensasi relatif lebih rendah. 2). Kemampuan dan kesediaan perusahaan membayar; Bahwa ukuran besar kecilnya kompensasi yang akan diberikann kepada karyawan akan sangat tergantung kepada kemampuan finansial yang dimiliki perusahaan, dan juga seberapa besar kesediaan dan kesanggupan perusahaan menentukan besarnya kompensasi untuk karyawannya. 3). Serikat buruh atau organisasi karyawan; Pentingnya eksistensi karyawan dalam perusahaan, maka karyawan akan membentuk suatu ikatan dalam rangka proteksi atas kesemenamenaan pimpinan dalam memberdayakan karyawan. Dalam hal ini muncul rasa yang menyatakan bahwa perusahaan tidak akan bisa mencapai tujuannya tanpa ada karyawan. Dengan demikian maka akan mempengaruhi besarnya kompensasi. 4). Produktivitas kerja/prestasi kerja karyawan; Kemampuan karyawan dalam menghasilka prestasi kerja akan sangat mempengaruhi besarnya kompensasi yang akan diterima karyawan. 5). Biaya hidup; Tingkat biaya hidup disuatu daerah akan menentukan besarnya kompensasi. 6). Posisi atau jabatan karyawan; Tingkat jabatan yang dipegang karyawan akan menentukan besar kecilnya kompensasi yang akan diterimanya, juga berat ringannya beban dan tanggung jawab suatu pekerjaan. 7). Tingkat pendidikan dan pengalaman kerja; Pendidikan dan pengalaman berperan dalam menentukan besarnya kompensasi bagi karyawan. Semakin tinggi pendidikan karyawan dan semakin banyak pengalaman kerja, maka semakin tinggi pula kompensasinya. 8). Sektor pemerintah; Pemerintah sebagai pelindung masyarakat berkewajiban untuk menerbitkan sistem kompensasi yang diterapkan perusahaan/organisasi, serta instansi-instansi lainnya, agar karyawan mendapatkan kompensasi yang adil dan layak, seperti dengan dikeluarkannya kebijakan pemerintah dalam pemberian upah minimum bagi karyawan".

$$
\text { Indikator kompensasi sesuai }
$$
dengan yang ada di peraturan dan dalam bentuk gaji, bonus, upah, hal tersebut dalam kompensasi finansial. namun dalam non finansialnya asuransi, tunjangan-tunjangan dan sebagainya. Setiap perusahaan memiliki indikator yang berbeda-beda dalam proses pemberian kompensasi untuk karyawan. Terdapat 2 (dua) indikator yang dikemukakan oleh Rivai (2015), yaitu: 1). 
"Kompensasi finansial langsung, yang terdiri dari: a). Gaji; Gaji adalah balas jasa dalam bentuk uang yang diterima karyawan sebagai konsekuensi dari kedudukannya sebagai seorang karyawan yang memberikan sumbangan tenaga dan pikiran dalam mencapai tujuan perusahaan atau dapat juga dikatakan sebagai bayaran tetap yang diterima seseorang dari keanggotaannya dalam sebuah perusahaan. b). Bonus; Bonus adalah pembayaran sekaligus yang diberikan karena memenuhi sasaran kinerja atau uang yang dibayar sebagai balas jasa atas hasil pekerjaan yang telah dilaksanakan apabila melebihi target. Bonus juga merupakan kompensasi tambahan yang diberikan kepada seorang karyawan yang nilainya diatas gaji normalnya. Bonus juga bisa digunakan sebagai penghargaan terhadap pencapaian tujuan-tujuan spesifik yang ditetapkan oleh perusahaan, atau untuk dedikasinya kepada perusahaan. c). Insentif; Insentif merupakan imbalan langsung yang dibayarkan kepada karyawan karena kinerjanya melebihi standar yang ditentukan. Insentif merupakan bentuk lain dari upah langsung di luar upah dan gaji yang merupakan kompensasi tetap, yang biasa disebut kompensasi berdasarkan kinerja. Insentif adalah variabel penghargaan yang diberikan kepada individu dalam suatu kelompok, yang diketahui berdasarkan perbedaan dalam mencapai hasil kerja. Ini di rancang untuk memberikan motivasi karyawan berusaha meningkatkan produktivitas kerjanya. 2). Kompensasi tidak langsung; Kompensasi tidak langsung merupakan kompensasi tambahan yang diberikan berdasarkan kebijakan perusahaan terhadap semua karyawan sebagai upaya meningkatkan kesejahteraan para karyawan. Contohnya berupa fasilitasfasilitas, seperti: asuransi-asuransi, tunjangan-tunjangan, uang pensiun, dan lain-lain. Dengan kompensasi organisasi bisa menciptakan, memelihara, dan mempertahankan produktivitas. Tanpa kompensasi yang memadai karyawan yang ada sekarang cenderung untuk keluar dari organisasi, tingkat absensi yang tinggi atau kedisiplinan yang rendah dan keluhan-keluhan lainnya yang bisa timbul".

\section{METODE PENELITIAN}

Penelitian menggunakan pendekatan kuantitatif yaitu melalui analisis inferensial tipe kausal. Penelitian berupaya untuk menelaah pengaruh variabel independen terhadap variabel dependen. Dalam penelitian ini populasinya adalah karyawan PT. Cipta Mandiri Wirasakti dengan jumlah karyawan 440 orang. Berdasarkan rumus Slovin didapat sampel dalam penelitian ini adalah sebanyak 82 orang. Pengumpulan data dalam penelitian ini menggunakan kuesioner yang bersifat tertutup. Metode analisis yang digunakan regresi linear sederhana dan berganda.

\section{HASIL PENELITIAN DAN PEMBAHASAN}

\section{Hasil Penelitian}

\section{Uji instrumen data}

Berdasarkan uraian tersebut, maka untuk dapat menentukan apakah variabel lingkungan kerja dan kompensasi dapat dijadikan pengukur terhadap kepuasan kerja karyawan PT. Cipta Mandiri Wirasakti. Namun sebelumnya data diolah terlebih dahulu dan dilakukan pengujian terhadap varibel yang digunakan yaitu lingkungan kerja, kompensasi dan kepuasan kerja karyawan untuk mengetahui apakah data tersebut akurat dan dapat dipercaya.

\section{Uji validitas}

Pengujian validitas ini dilakukan untuk menguji apakah tiap butir pernyataan telah mewakili indikator yang 
akan diteliti, persyaratan minimum untuk dapat dikatakan valid adalah $r=0,30$. Jadi, apabila korelasi antara butir-butir item pernyataan dengan skor total kurang dari 0,30, maka butiran dalam instrumen tersebut dapat dikatakan tidak valid. Uji validitas dilakukan dengan melihat korelasi antara skor masing-masing item pernyataan dengan skor total. (Sugiyono, 2018).

\section{Uji reliabilitas}

Pengujian reliabilitas ini dilakukan untuk menguji seberapa jauh hasil pengukuran yang dapat diandalkan secara konsisten. Pada tabel hasil pengujian
Dari perhitungan koefisien korelasi skor tiap butir pernyataan instrumen dari 82 responden tentang lingkungan kerja dengan jumlah 7 butir pernyataan; instrumen kompensasi 8 butir pernyataan dan instrumen kepuasan kerja 8 butir pernyataan dengan total skor setiap responden diperoleh hasilnya valid dimana $\mathrm{r}$ hitung lebih besar dari $\mathrm{r}$ kritis 0,300 .

reliabilitas berikut, diketahui bahwa semua variabel mempunyai alpha di atas 0.6 yang berarti bahwa semua variabel dalam penelitian ini dapat diandalkan.

Tabel 1: Hasil Uji Reliabilitas

\begin{tabular}{lccc}
\hline \multicolumn{1}{c}{ Variabel } & $\begin{array}{c}\text { Cronbach } \\
\text { Alpha }\end{array}$ & $\begin{array}{c}\text { Nilai kritis } \\
(\boldsymbol{\alpha})=\mathbf{5 \%}\end{array}$ & Keterangan \\
\hline Lingkungan Kerja & 0.724 & 0.600 & Reliabel \\
Kompensasi & 0.614 & 0.600 & Reliabel \\
Kepuasan Kerja & 0.615 & 0.600 & Reliabel \\
\hline
\end{tabular}

Sumber: Data Primer, diolah tahun 2021

Berdasarkan angka-angka reliabilitas cronbach alpha tersebut tampak bahwa seluruh pernyataan yang ada membentuk ukuran yang reliabel lingkungan kerja, kompensasi, dan kepuasan kerja karyawan membentuk ukuran yang reliabel dari masing-masing variabel.

\section{Analisis regresi linear sederhana}

Tabel 2: Pengaruh Lingkungan Kerja Terhadap Kepuasan Kerja

\begin{tabular}{lcccccc}
\hline & \multicolumn{6}{c}{ Parameter } \\
\cline { 2 - 6 } Variabel & $\mathbf{R}$ & $\begin{array}{c}\mathbf{R} \\
\text { Square }\end{array}$ & $\begin{array}{c}\text { Konst } \\
\text { anta }\end{array}$ & $\begin{array}{c}\text { Koefisien } \\
\text { Regresi }\end{array}$ & Sig & $\boldsymbol{\alpha}$ \\
\hline Ling_Kerja & 0,801 & 0,642 & 10,147 & 0,787 & 0,000 & 0,01 \\
\hline Pengujian Signifikan & & & & & \\
\hline t hitung = 11,967 & \multicolumn{1}{c}{}
\end{tabular}

Keterangan: Variabel Kepuasan Kerja

Sumber: data diolah 2021

Tabel 2, nilai koefisien determinasi $\left(\mathrm{R}^{2}\right)$ sebesar 0.642 , artinya lingkungan kerja memberikan kontribusi sebesar 64,2\% kepada kepuasan kerja karyawan PT. Cipta Mandiri Wirasakti, sedangkan sisanya sebesar $35,8 \%$ disumbangkan faktor lain yang tidak diteliti.
Persamaan Regresi $\mathrm{Y}=10,147+0,787$ $\left(\mathrm{X}_{1}\right)$

Lingkungan kerja berpengaruh positif dan signifikan pada tingkat nyata 99\% terhadap kepuasan kerja karyawan 
PT. Cipta Mandiri Wirasakti. Koefisien lingkungan kerja sebesar 0,787, artinya jika ada peningkatan lingkungan kerja, maka kepuasan kerja karyawan PT. Cipta Mandiri Wirasakti akan meningkat.

Untuk menguji hubungan kausalitas secara parsial variabel lingkungan kerja terhadap kepuasan kerja karyawan PT. Cipta Mandiri Wirasakti signifikan atau tidak, dilakukan pengujian dengan menggunakan signifikansi probabilitas dengan tingkat kepercayaan 5\%, dimana sig. 0,000 lebih kecil dari 0,05. Berdasarkan hasil tersebut, maka Ho tolak, Ha terima, diartikan terdapat pengaruh yang positif dan signifikan variabel lingkungan kerja terhadap kepuasan kerja karyawan PT. Cipta Mandiri Wirasakti.

Tabel 3: Pengaruh Kompensasi Terhadap Kepuasan Kerja

\begin{tabular}{lcccccc}
\hline & \multicolumn{6}{c}{ Parameter } \\
\cline { 2 - 7 } Variabel & $\mathbf{R}$ & $\begin{array}{c}\mathbf{R} \\
\text { Square }\end{array}$ & $\begin{array}{c}\text { Kons } \\
\text { tanta }\end{array}$ & $\begin{array}{c}\text { Koefisien } \\
\text { Regresi }\end{array}$ & Sig & $\boldsymbol{\alpha}$ \\
\hline Kompensasi & 0,715 & 0,511 & 8,867 & 0,756 & 0,000 & 0.01 \\
\hline Pengujian Signifikan \\
\hline \multicolumn{1}{l}{ thitung = 9,146 } \\
\hline
\end{tabular}

Keterangan: Variabel Kepuasan Kerja

Sumber: data diolah 2021

Tabel 3, nilai koefisien determinasi $\left(\mathrm{R}^{2}\right)$ sebesar 0.511, artinya kompensasi memberikan kontribusi sebesar $51,1 \%$ kepada kepuasan kerja karyawan PT. Cipta Mandiri Wirasakti, sedangkan sisanya sebesar $49,9 \%$ disumbangkan faktor lain yang tidak diteliti.

Persamaan Regresi $\mathrm{Y}=8,867+0,756\left(\mathrm{X}_{2}\right)$

Kompensasi berpengaruh positif dan signifikan pada tingkat nyata $99 \%$ terhadap kepuasan kerja karyawan PT. Cipta Mandiri Wirasakti. Koefisien kompensasi sebesar 0,756, artinya jika ada peningkatan kompensasi, maka kepuasan kerja karyawan PT. Cipta Mandiri Wirasakti akan meningkat.

Untuk menguji hubungan kausalitas secara parsial variabel kompensasi terhadap kepuasan kerja karyawan PT. Cipta Mandiri Wirasakti signifikan atau tidak, dilakukan pengujian dengan menggunakan signifikansi probability dengan tingkat kepercayaan 5\%, dimana sig. 0,000 lebih kecil dari 0,05. Berdasarkan hasil tersebut. Berdasarkan hasil tersebut, maka Ho tolak, Ha terima, diartikan terdapat pengaruh yang positif dan signifikan variabel kompensasi terhadap kepuasan kerja karyawan PT. Cipta Mandiri Wirasakti.

\section{Analisis regresi linear berganda}

Tabel 4: Pengaruh Lingkungan Kerja dan Kompensasi Terhadap Kepuasan Kerja

\begin{tabular}{ccccc}
\hline \multirow{2}{*}{ Variabel } & \multicolumn{4}{c}{ Parameter } \\
\cline { 2 - 6 } & Mult. & $\mathbf{R}$ & Konstanta & Koefisien \\
Regresi & Sig. \\
\hline
\end{tabular}




\begin{tabular}{lllll}
\hline Ling_Kerja $\quad 0,849 \quad 0,721$ & \multirow{2}{*}{4,577} & 0,494 & 0,002 \\
Kompensasi $\quad 0,536$ & 0,004 \\
\hline Pengujian Signifikan & & & \\
\hline F hitung = 102,225 & & \\
\hline Keterangan: Variabel Kepuasan Kerja \\
Sumber: data diolah 2021
\end{tabular}

Tabel 4, nilai $\mathrm{F}$ hitung sebesar 30,339 atau melihat $\mathrm{F}$ signifikan yaitu sebesar 0,000 lebih kecil dari tingkat kepercayaan 0,05. maka Ho tolak, Ha terima, artinya secara bersama-sama kompetensi dan motivasi berpengaruh positif dan signifikan pada tingkat nyata 99\% terhadap kinerja karyawan PT Indonesia Epson Industry,

Nilai Koefisien Determinasi $\left(\mathrm{R}^{2}\right)$ sebesar 0.721, artinya lingkungan kerja dan kompensasi secara bersama-sama memberikan kontribusi sebesar 72,1\% kepada kepuasan kerja karyawan PT. Cipta Mandiri Wirasakti, sedangkan sisanya sebesar $27,9 \%$ disumbangkan faktor lain yang tidak dibahas dalam penelitian ini.

Persamaan Regresi $\mathrm{Y}=4,254+0,571$ $\left(\mathrm{X}_{1}\right)+0,378\left(\mathrm{X}_{2}\right)$

Lingkungan kerja dan kompensasi berpengaruh positif dan signifikan terhadap kepuasan kerja karyawan PT. Cipta Mandiri Wirasakti pada tingkat nyata $99 \%$. Koefisien lingkungan kerja sebesar 0,571 , artinya jika ada perbaikan lingkungan kerja, maka kepuasan kerja karyawan PT. Cipta Mandiri Wirasakti akan meningkat atau sebaliknya dengan asumsi kompensasi tidak berubah. Koefisien kompensasi sebesar 0,378, artinya jika ada peningkatan kompensasi, maka kepuasan kerja karyawan PT. Cipta Mandiri Wirasakti akan meningkat atau sebaliknya, dengan asumsi lingkungan kerja tidak berubah.

\section{Pembahasan}

\section{Pengaruh Lingkungan Kerja Terhadap Kepuasan Kerja Karyawan PT. Cipta Mandiri Wirasakti}

Hasil penelitian ini menunjukkan bahwa lingkungan kerja yang baik dapat mendorong peningkatan kepuasan kerja karyawan. Hal ini dapat dilihat bangunan tempat kerja manarik dan nyaman untuk bekerja, peralatan kerja yang sangat memadai untuk mendukung pekerjaan, fasilitas tempat istirahat dan ibadah tersedia cukup bersih, tersedia sarana angkutan antar jemput karyawan, hubungan kerja yang harmonis antar rekan kerja, saling menghargai, terjalin kerjasama yang baik dalam membantu penyelesaiaan pekerjaan. Hasil penelitian ini sesuai dengan penelitian yang dilakukan oleh Kusumah (2016) dan Tumboimbela (2018), yaitu menganalisis pengaruh lingkungan kerja terhadap kepuasan kerja karyawan. Dengan demikian hipotesis pertama diterima.

\section{Pengaruh Kompensasi Terhadap Kepuasan Kerja Karyawan PT. Cipta Mandiri Wirasakti}

Hasil penelitian ini menunjukkan bahwa kompensasi dapat mendorong peningkatan kepuasan kerja karyawan. Hal ini dikarenakan bahwa gaji yang diterima sesuai harapan dan usaha yang dikeluarkan oleh karyawan, mendapatkan bonus bagi karyawan yang memenuhi sasaran kerja, insentif bagi karyawan yang tingkat produktivitas kerja tinggi, insentif yang diberikan dapat meningkatkan semangat kerja, perusahaan memberikan jaminan asuransi atas resiko kecelakaan kerja, adanya tunjangan sesuai jabatan yang ditempati karyawan dan perusahaan 
memberikan uang pensiun bagi yang sudah selesai masa kerjanya. Hasil penelitian ini sejalan dengan penelitian yang dilakukan oleh Hatang, et al, (2016) dan Yaseen (2013), yaitu menganalisis pengaruh kompensasi terhadap kepuasan kerja karyawan. Dengan demikian hipotesis kedua diterima.

\section{Pengaruh Secara Simultan Lingkungan Kerja dan Kompensasi Terhadap Kepuasan Kerja Karyawan PT. Cipta Mandiri Wirasakti}

Berdasarkan hasil analisis diketahui bahwa lingkungan kerja dan kompensasi dapat mendorong peningkatan kepuasan kerja karyawan PT. Cipta Mandiri Wirasakti. Hasil penelitian ini sama dengan hasil penelitian yang dilakukan oleh Dwijayanti \& Dewi (2015) dan Fauzi (2017), yaitu menganalisis pengaruh lingkungan kerja dan kompensasi terhadap kepuasan kerja karyawan. Dengan demikian hipotesis ketiga diterima.

\section{KESIMPULAN DAN SARAN}

\section{Kesimpulan}

Berdasarkan hasil analisis yang dilakukan, maka kesimpulan yang dapat dukemukakan dalam penelitian ini adalah sebagai berikut: 1). Lingkungan kerja mendorong peningkatan kepuasan kerja karyawan PT. Cipta Mandiri Wirasakti. 2). Kompensasi mendorong peningkatan kepuasan kerja karyawan PT. Cipta Mandiri Wirasakti. 3). Lingkungan kerja dan kompensasi mendorong kepuasan kerja karyawan PT. Cipta Mandiri Wirasakti.

\section{Saran}

Berdasarkan hasil penelitian, berikut ini diberikan beberapa saran untuk meningkatkan kepuasan kerja karyawan PT. Cipta Mandiri Wirasakti sebagai berikut: 1). PT. Cipta Mandiri Wirasakti hendaknya dapat mempertahankan dan meningkatkan lingkungan kerja yang sudah ada, baik lingkunan kerja fisik dan non fisik, hal ini dapat dilakukan dengan cara mengatur suhu di ruangan kerja sehingga dapat mendukung karyawan dalam bekerja, mengatur tingkat kebisingan, hubungan antar karyawan yang bersifat persaudaraan, hubungan antara atasan dengan bawahan dapat berjalan dengan baik. 2). PT. Cipta Mandiri Wirasakti memperhatikan masalah kompensasi, baik kompensasi langsung maupun tak langsung sehingga karyawan akan merasa puas dalam bekerja dan diharapkan kinerja akan meningkat. 3). Penelitian selanjutnya, perlu dilakukan penelitian yang sejenis dengan menambah variabel penelitian selain dari variabel yang ada seperti budaya organisasi, komitmen organisasi, dan motivasi kerja agar penelitian tentang kepuasan kerja ini menjadi lebih baik lagi.

\section{DAFTAR PUSTAKA}

Afandi, P. 2018. Manajemen Sumber Daya Manusia (Teori, Konsep dan Indikator). Riau: Zanafa Publishing. Ahyari. 2014. Manajemen Sumber Daya Manusia dan Lingkungan Kerja. Bandung: Pioner Jaya.

Casson, Herbert N. 2013. Efisiensi Perusahaan. Jakarta: Erlangga.

Dawal, Siti Zawiah Md and Taha, Zahari. 2006. The Effect of Job and Environmental Factors on Job Satisfaction in Automotive Industries. International Journal of Occupational Safety and Ergonomics(JOSE). Vol.12, No.3, 267-280.

Dessler, Gerry. 2015. Manajemen Sumber Daya Manusia. Jakarta: Salemba Empat.

Dwijayanti, Made Nensy dan Dewi, A.A Sagang Kartika. 2015. "Pengaruh Kompensasi dan Lingkungan Kerja Terhadap Kepuasan Kerja Karyawan Pada PDAM Tirta 
Mangutama Badung”. E-Jurnal Manajemen Unud, Vol. 4, No. 12, 2015: 4274-4301. ISSN: 23028912.

Fauzi. 2017. "Pengaruh Kompensasi dan Lingkungan Kerja Terhadap Kepuasan Kerja Karyawan PT. Tor Ganda Medan". Jurnal Riset Manajemen \& Bisnis (JRMB), Vol. 2 No. 3 Oktober 2017. Hal. 36-47. ISSN: 2339-0506.

Handoko, T. Hani. 2017. Manajemen Personalia dan Sumberaya Manusia. Yogyakarta: BPFE.

Hasibuan, Malayu S.P. 2017. Manajemen Sumber Daya Manusia. Jakarta: PT. Bumi Aksara.

Hatang, Ikhwanuddin A.M. 2016. "Pengaruh Kompensasi dan Lingkungan Kerja Terhadap Kepuasan Kerja Pegawai Dinas Pendapatan, Pengelolan Keuangan dan Aset Daerah Kabupaten Soppeng”. Jurnal Mirai Management, Volume 1 Nomor 2, Oktober 2016. Hal. 495-515.

Kusumah, Dadang Heri. 2016. "Pengaruh Lingkungan Kerja dan Kompensasi Terhadap Kepuasan Kerja Karyawan PT. Sinar Lentera Kencana Cikarang”. Jurnal Pengembangan Wiraswasta. Vol. 18 No. 1 April 2016. Hal. 71-80.

Mangkunegara, Anwar Prabu. 2017. Manajemen Sumber Daya Manusia Perusahaan, Cetakan Kesepuluh, Bandung: PT. Remaja Rosdakarya.

Nawawi, Hadari. 2012. Manajemen Sumber Daya Manusia Untuk Bisnis yang Komptitif. Yogyakarta: Gadjah Mada University Press.

Nitisemito, Alex S. 2015. Manajemen dan Sumber Daya Manusia. Bandung: Pustaka Setia.

Notoatmodjo, $\quad$ Soekidjo. 2009. Pengembangan Sumber Daya Manusia. Jakarta: PT. Rineka Cipta.
Priansa, Donni Juni. 2016. Perencanaan dan Pengembangan Sumber Daya Manusia. Bandung: Alfabeta

Rivai, Veithzal. 2015. Manajemen Sumber Daya Manusia Untuk Perusahaan Dari Teori Ke Praktek. Bandung: Rajagrafindo persada.

Robbins, Stephen. P. 2007. Perilaku Organisasi. Jakarta: PT. Indeks Gramedia.

Saydam, Gouzaly. 2014. Manajemen Sumber Daya Manusia. Jakarta: Gunung Agung.

Sedarmayanti. 2017. Manajemen Sumber Daya Manusia. Bandung: PT. Refika Aditama.

Siagian, Sondang P. 2015. Manajemen Sumber Daya Manusia. Jakarta: Bumi Aksara.

Sugiyono. 2018. Statikstika Untuk Penelitian. Bandung: Alfabeta.

Sunyoto, Danang. 2012. Manajemen Sumber Daya Manusia. Jakarta: PT. Buku Seru.

Sutrisno, Edy 2016, Manajemen Sumber Daya Manusia, Cetakan Kedelapan, Jakarta: Prenamedia Group.

Tumboimbela, Syela C.S. 2018. "The Impact of Work Environment Toward Job Satisfaction at PT. Post Main Branch Office in Manado". Jurnal EMBA. Vol. 6 No. 2 April 2018, Hal. 788-797. ISSN: 23031174.

Wibowo. 2014. Manajemen Kinerja. Edisi Ke Empat. Jakarta: Rajawali Press.

Yaseen, Ayesha. 2013. "Effect of Compensation Factors on Employee Satisfaction- A Study of Doctor"s Dissatisfaction in Punjab". International Journal of Human Resource Studies. Vol. 3, No. 1, 2013. Pp. 142-157. ISSN: 21623058. 
This work is licensed under a Creative Commons Attribution-NonCommercial-ShareAlike 4.0 International License. Ciptaan disebarluaskan di bawah Lisensi Creative Commons Atribusi-BerbagiSerupa 4.0 Internasional. 